\title{
Pendidikan pemilih bagi pemula dalam menciptakan pemilih melek politik di Kabupaten Lampung Selatan dan Kota Bandar Lampung pada Pilkada serentak 2020
}

\author{
Himawan Indrajat*, Arizka Warganegara, Robi Cahyadi Kurniawan, \& Budi Kurniawan
}

\author{
Fakultas Ilmu Sosial dan Politik, Universitas Negeri Lampung \\ * himawan.indrajat@fisip.unila.ac.id
}

\begin{abstract}
Abstrak. Tujuan pengabdian ini adalah memberikan pendidikan pemilih kepada pemilih pemula di Kota Bandar Lampung dan Kabupaten Lampung Selatan, karena di bulan desember 2020 nanti dua kabupaten/Kota akan melaksanakan pemilihan kepala daerah secara serentak. Diharapkan dengan diberikannya pendidikan pemilih tingkat pengetahuan pemilih akan meningkat sehingga yang diharapkan pemilih tidak sekadar paham tentang haknya sebagai warga negara untuk memilih tetapi juga mengerti maksud dan tujuan pilkada. Pengayaan pengetahuan dan pemahaman peserta melalui pengisian pertanyaan secara online di google form. Cara ini digunakan untuk mengetahui tingkat pengetahuan dan pemahaman peserta tentang demokrasi, pilkada, dan partisipasi politik. Serta memberikan materi seminar yang berkaitan dengan pertanyaan pada kuesioner. Evaluasi akhir melalui diskusi mengenai materi yang belum dipahami dan mengukur peningkatan pengetahuan dengan meminta peserta mengisi kuesioner kembali. Pengabdian dilaksanakan melalui daring lewat aplikasi zoom dan tatap muka fisik, karena kondisi pandemi COVID-19 dan juga karena lokasi pengabdian ada di dua tempat dan dilaksanakan secara bersamaan. Hasil pengabdian menunjukkan bahwa tidak semua peserta pengabdian mengetahui tentang pilkada serentak akan dilaksanakan pada bulan desember nanti. Dan masih ada peserta yang belum mengerti bahwa hak memilih bukanlah kewajiban sebagai warga negara. Serta masih adanya peserta yang belum mengetahui tentang lembaga penyelenggara pemilu yaitu Komisi Pemilihan Umum dan Badan Pengawas Pemilu. Dan terdapat cukup banyak pemilih pemula yang tertarik untuk menerima politik uang. Ini menunjukan bahwa perlunya kegiatan pengabdian ini, untuk memberikan pengetahuan politik pada pemilih pemula. Setelah kami memberikan materi kemudian diskusi, dan meminta peserta untuk mengisi kuesioner ulang, terdapat peningkatan pengetahuan pada peserta seperti pengetahuan tentang pelaksanaan pilkada dan dampak buruk politik uang.
\end{abstract}

Kata kunci: Pilkada, pemilih pemula, pendidikan pemilih

\begin{abstract}
This community service provides voter education to first-time voters in Bandar Lampung City and Lampung Selatan Regency. In December these two regencies/cities will hold a regional head election simoustanly. It is hoped that by providing voter education, the level of voters political knowledge can increase will not only understand their rights as citizens to vote but also understand the aims and objectives of the elections, understand democracy, regional head elections, and political participation so that new voters hope to become smart and politically literate voters. This service was carried out to assess the knowledge and understanding of the seminar participants using an initial evaluation by filling out an online questionnaire via google form. This method is used to determine the level of knowledge and understanding of participants about democracy, regional elections, and political participation. As well as providing seminar materials related to regional elections, political participation, and public policy. Final evaluation through discussion on issues that have not been understood related to the material presented and the increase in participant knowledge. The number of participants for the voter education service for beginners is 40 people is carried out online through the Zoom application and face-to-face physical because of the COVID-19 pandemic conditions and also because of the service location is in two places and carried out at the same time. Many participants do not know that in December, the regional elections will hold simultaneously. And there are still participants who think that voting during the elections is an obligation as a citizen, not a citizen's right. And there are always participants who do not know about the election management institutions, namely the General Election Commission and the Election Supervisory Board. In the interest to accept money politics, many new voters are interested in receiving money politics on election day. It shows that some beginner voters are willing to take money politics in the upcoming regional elections, so it is necessary to understand that money politics destroys democracy. After filling in the questionnaire, we provided materials about democracy, regional elections, political participation, and money politics. We offer the understanding to voters that the goal of democracy is to create a government that can provide prosperity to its people, and there are ways to select regional head candidates through elections, so voters must be critical to see the track records and backgrounds of local head candidates so that the correct regional head is elected. true in accordance with the aspirations of society.
\end{abstract}

Keywords: Head local election, first time voters, voters education 


\author{
To cite this article: Indrajat, H., A. Warganegara., R. C. Kurniawan., \& B. Kurniawan. 2020. Pendidikan pemilih \\ bagi pemula dalam menciptakan pemilih melek politik di Kabupaten Lampung Selatan dan Kota Bandar Lampung \\ pada Pilkada serentak 2020. Unri Conference Series: Community Engagement 2: 303-309. \\ https://doi.org/10.31258/unricsce.2.303-309 \\ (C) 2020 Authors \\ Peer-review under responsibility of the organizing committee of Seminar Nasional Pemberdayaan Masyarakat 2020
}

\title{
PENDAHULUAN
}

Pada bulan desember 2020 nanti akan dilaksanakan pemilihan kepala daerah secara serentak di 270 daerah, dengan rincian 224 pemilihan bupati dan 37 walikota serta 9 pemilihan gubernur. Provinsi Lampung adalah salah satu daerah yang akan menyelenggarakan pemilih kepala daerah secara serentak tersebut, terdapat 8 kabupaten/kota yang akan melaksanakan pesta rakyat memilih kepala daerah yaitu Kota Bandar Lampung, Kota Metro, Kabupaten Lampung Selatan, Kabupaten Lampung Tengah, Kabupaten Pesisir Barat, Kabupaten Lampung Timur, Kabupaten Way Kanan dan Kabupaten Pesawaran. Dengan Pemilihan Kepala Daerah Langsung, rakyat akan memiliki kedaulatan penuh untuk mengekspresikan hak-hak politiknya memilih calon kepala daerah yang menurut mereka memang mampu dan layak untuk memimpin daerah tersebut.

Pada perkembangannya aturan hukum mengenai pilkada mengalami banyak perubahan, pada awal pelaksanaan pilkada langsung di tahun 2005 undang-undang yang mengatur adalah UU No. 32 Tahun 2004 tentang pemerintahan daerah. Kemudian pilkada diatur secara khusus melalui Undang-undang Nomor 12 Tahun 2007 tentang Pemilihan Kepala Daerah. Pada tahun 2014 sempat muncul kontroversi ketika Dewan Perwakilan Rakyat periode 2009-2014 pada akhir masa jabatannya mengesahkan Undang-undang Nomor 22 Tahun 2014 tentang pemilihan kepala daerah tidak lagi dipilih secara langsung tapi dipilih oleh DPRD. Sehingga memunculkan penolakan dari masyarakat. Kemudian presiden Susilo Bambang Yudhoyono merespon dengan menerbitkan Peraturan Pemerintah Pengganti Undang-undang Nomor 1 Tahun 2014 yang mencabut Undang-Undang Nomor 22 Tahun 2014 yang mengatur bahwa kepala daerah dipilih oleh DPRD. http://nasional.tempo.co/read/news/2015/02/17/078643284/Hujan-Interupsi-Warnai-Pengesahan-

RevisiRUU-Pilkada). Kemudian DPR akhirnya mengesahkan Perpu Nomor 1 Tahun 2014 tentang Pemilihan Kepala Daerah menjadi Undang-undang Nomor 2 Tahun 2015. Dan terakhir terkait pandemi covid-19 disahkan UU N0. 6 Tahun 2020 yang mengatur pelaksanaan Pilkada di masa pandemik ini

Pilkada langsung juga merupakan even politik penting, karena merupakan arena kompetisi bagi para politisi lokal untuk memperebutkan jabatan Kepala Daerah dengan menggunakan segala sumber daya yang dimilikinya. Sehingga Pilkada merupakan arena tempat berlangsungnya pertarungan kekuatan politik, kekuatan ekonomi, maupun kekuatan sosial untuk meraih simpati pemilih dan merebut kekuasaan di tingkat lokal (Bambang Purwoko, 2005). Akibatnya kondisi ideal sebagai arena pembelajaran politik tidak terjadi karena para kandidat mengerahkan seluruh sumber daya yang dimiliki terutama kekuatan politik dan ekonomi untuk memenangi pemilihan kepala daerah melalui pengerahan birokrasi apalagi calon tersebut merupakan petahana, menggunakan politik uang untuk membeli partai politik dan membeli suara rakyat. Kondisi ini tentu membahayakan perkembangan demokrasi di Indonesia pada umumnya dan daerah pada khususnya, karena tujuan dari pilkada langsung adalah mewujudkan demokrasi ditingkat lokal sebagai dasar tumbuh berkembang demokrasi di tingkat nasional. Oleh karena itu kegiatan pendidikan pemilih agar pemilih dapat memiliki pengetahuan politik sehingga tidak mudah dibeli suaranya oleh kandidat.

Pada penyelenggaraan pemilu terdapat suatu kategori kelompok pemilih yang sangat menarik untuk diamati dan diteliti lebih jauh, yaitu pemilih pemula. Karena kasus politik uang dan mobilisasi pemilih tidak hanya menyerang para pemilih yang sudah dewasa, tetapi juga pemilih pemula tidak lepas dari peredaran kasus politik uang dan mobilisasi. Hal ini terjadi karena mereka belum mengerti benar tentang pendidikan pemilih sehingga jenis partisipasi mereka hanyalah partisipasi yang dimobilisasi bukan karena kesadaran pribadi. Oleh karena itu diperlukan pendidikan pemilih untuk mendidik pemilih agar menjadi pemilih yang cerdas dan melek politik terutama kepada generasi muda pemilih pemula.

Data jumlah pemilih pemula pada pemilihan kepala daerah tahun 2020 di Kota Bandar Lampung dan Kabupaten Lampung Selatan belum terdata, tetapi data jumlah pemilih pemula pada Pileg dan Pilpres 2019 dapat dijadikan patokan dalam pemberian pendidikan pemilih. Karena jumlah pemilih pemula pasti bertambah jumlah, berikut ini di kota Bandar Lampung pada pemilu 2019 berdasarkan data yang diperoleh dari Komisi Pemilihan Umum (KPU) kota Bandar Lampung dan Kabupaten Lampung Selatan, pemilih pemula di Kota 
Bandar Lampung berjumlah 14.930 orang. Kemudian jumlah pemilih pemula di Kabupaten Lampung Selatan berjumlah 16.429 orang.

Pengaruh pemilih muda yang penting dan signifikan pada pemilu sudah disadari oleh partai politik peserta pemilu dan para calon kandidatnya. Banyak yang sudah mulai memperhitungkan suara dari pemilih muda dalam proses kampanye sehingga tidak jarang berbagai cara dilakukan untuk bisa menghimpun suara para pemilih muda ini. Salah satu yang harus menjadi perhatian khusus adalah pendidikan politik yang masih rendah di kalangan pemilih muda atau bisa disebut juga sebagai pemilih pemula tersebut. Pendidikan politik yang masih rendah membuat kelompok ini rentan dijadikan sasaran untuk dimobilisasi oleh kepentingankepentingan tertentu (Wardhani, 2018:58).

Oleh karena itu tujuan dari pengabdian kepada masyarakat ini adalah, (1) Agar pemilih pemula menjadi pemilih yang cerdas dan melek politik. Sehingga mereka tidak menjadi sasaran mobilisasi dari calon kepala daerah dan tidak bisa dibeli suaranya dengan politik uang. (2) Menciptakan kader demokrasi untuk menyebarkan pentingnya menjadi pemilih cerdas pada masyarakat. Karena pemilih pemula adalah generasi muda harapan bangsa apabila mereka menjadi individu yang cerdas maka diharapkan dapat membawa perubahan demokrasi yang lebih baik.

\section{Kajian literatur}

\section{Demokrasi}

Demokrasi adalah sebuah bentuk pemerintahan rakyat. Jalan konkrit untuk mengorganisasikan bentuk pemerintahan ini dan pertanyaan mengenai kondisi dan prakondisi yang dibutuhkan telah diperdebatkan secara intensif (Sorensen, 2003) Istilah demokrasi sendiri berasal dari gabungan dua kata bahasa Yunani: yaitu demos (yang berarti rakyat) dan kratos (pemerintah) jadi definisi dari demokrasi adalah "pemerintahan oleh rakyat".

Juan Linz mendefinisikan demokrasi sebagai berikut apakah dalam suatu sistem politik pemerintah memberikan ruang gerak yang cukup bagi warga masyarakatnya untuk melakukan partisipasi guna memformulasikan preferensi politik mereka melalui organisasi politik yang ada. Di samping itu, sejauh mana kompetisi antar pemimpin dalam sistem demokrasi dilakukan secara teratur dalam mengisi jabatan politik baik itu di tingkat nasional maupun lokal (Affan Gaffar, 2006).

Ada beberapa unsur atau prinsip-prinsip demokrasi secara umum yang dianggap penting, yaitu: 1) keterlibatan warga negara dalam pembuatan keputusan politik, 2) tingkat persamaan tertentu diantara warga negara, 3) tingkat kebebasan atau kemerdekaan tertentu yang diakui dan dipakai oleh para negara, 4) suatu sistem perwakilan, 5) suatu sistem pemilihan - kekuasaan mayoritas. (Rahman, 2002).

\section{Literasi politik (melek politik) dan partisipasi politik}

Menurut Bernard Crick (2006), literasi politik adalah pemahaman praktis tentang konsep konsep yang diambil dari kehidupan sehari hari dan bahasa. Merupakan upaya memahami seputar isu politik, keyakinan para kontestan, bagaimana kecenderungan mereka mempengaruhi diri sendiri dan orang lain. Singkatnya literasi politik merupakan senyawa dari pengetahuan, keterampilan dan sikap mengenai politik. Mengenai literasi politik ini juga dijelaskan oleh Jenni S Bev sebagai keterampilan yang diperlukan oleh masyarakat untuk berpartisipasi dalam pemerintahan (NE. Putri, 2017)

Menurut Denver dan Hands (1990) dalam Karim dkk. (2015:5), Literasi Politik (political literacy) merupakan pengetahuan dan pemahaman tentang proses politik dan isu-isu politik, suatu pengetahuan dan pemahaman yang memungkinkan setiap warga negara dapat secara efektif melaksanakan perannya (berperan serta, partisipasi) sebagai warga negara. Pengetahuan dan pemahaman ini oleh Cassel dan Lo (1997) sebagaimana dikutip Karim dkk. (2015:5) disebut sebagai political expertise dan political awareness, yang intinya merujuk pada maksud sejauh mana seorang individu warga negara memberi perhatian dan memahami isu-isu politik (Agus Sutisna, 2017)

Partisipasi politik merupakan bagian yang tidak dapat dipisahkan dari perilaku politik warga negara. Definisi partai politik menurut Huntington dan Nelson adalah kegiatan warga negara preman (private citizen) yang bertujuan mempengaruhi pengambilan keputusan oleh pemerintah. Partisipasi bisa bersifat individual atau kolektif, terorganisir atau spontan, mantap atau sporadis, damai atau dengan kekerasan, legal atau ilegal. Efektif atau tidak efektif (Samuel P. Huntington, 1996:6).

\section{Pemilih pemula}

Pasal 1 ayat 33 Undang-Undang No 7 Tahun 2017 tentang pemilih, pemilih adalah Warga Negara Indonesia yang sudah genap berumur 17 (tujuh belas) tahun atau lebih, sudah kawin, atau sudah pernah kawin. Kemudian pasal 198 ayat 1 Undang-Undang No 7 tahun 2017 menerangkan bahwa pemilih yang mempunyai hak memilih 
adalah Warga Negara Indonesia yang pada hari pemungutan suara sudah genap 17 (tujuh belas) tahun atau lebih sudah kawin, atau sudah pernah kawin mempunyai hak memilih.

Pemilih pemula secara umum mereka para pelajar, mahasiswa serta pekerja yang berusia muda. Dalam pesta demokrasi pemilih pemula selama ini menjadi sebuah objek kegiatan politik. Yaitu mereka yang memerlukan bimbingan kearah pertumbuhan potensi dan kemampuan tingkat yang optimal agar dapat berperan baik dalam kegiatan politik. Pemilih pemula dalam kategori politik adalah "kelompok yang baru pertama kali menggunakan hak pilihnya. Orientasi politik pemilih pemula ini selalu dinamis dan akan berubahubah mengikuti kondisi yang ada dan faktor-faktor yang mempengaruhinya" (Prasetyo dkk, 2019: 94-95)

Pemilih pemula yang terdiri atas pelajar, mahasiswa atau pemilih dengan rentang usia 17-21 tahun menjadi segmen yang memang unik, seringkali memunculkan kejutan dan tentu menjanjikan secara kuantitas. Wardhani (2018:59) mengatakan "disebut unik, sebab perilaku pemilih pemula dengan antusiasme tinggi, relatif lebih rasional, haus akan perubahan dan tipis akan kadar polusi pragmatisme".

\section{METODE PENERAPAN}

Metode yang digunakan dalam pengabdian kepada masyarakat yang bertema "Pendidikan Pemilih Kepada Pemilih Pemula di Kabupaten Lampung Selatan dan Kota Bandar Lampung" dengan pendekatan: 1) Pemberian Pre Test dan Post Test berupa pengisian pertanyaan di Google Form untuk mengukur pengetahuan peserta sebelum pemberian materi dan sesudahnya. 2) Partisipatif Pendekatan Partisipatif, Dilakukan secara koordinatif, melibatkan Tim Pelaksana (Dosen dan mahasiswa) dengan Mitra (Pemilih Pemula). 3) Pendekatan Teori dan Praktek, Dilakukan melalui kegiatan pembelajaran, tatap muka dan penugasan baik teori maupun praktik. 4) Pendampingan, Dilakukan dengan evaluasi kegiatan selanjutnya dilakukan refleksi dan keberlanjutan dalam bentuk monitoring dan pendampingan, baik terprogram maupun insidental guna menjaga kualitas hasil kegiatan serta meningkatkan kemitraan.

\section{HASIL DAN KETERCAPAIAN SASARAN}

Hasil pengabdian kami terhadap pemilih pemula di Kota Bandar Lampung dan Kabupaten Lampung Selatan menunjukkan bahwa masih ada pemilih pemula yang belum memiliki pengetahuan politik yang memadai dan mereka cenderung mudah dipengaruhi menggunakan politik uang. Menjadi tugas penyelenggara pemilu yaitu Komisi Pemilihan Umum dan Badan Pengawas Pemilu untuk memberikan pendidikan politik kepada pemilih pemula ini bukan sekedar melakukan sosialisasi cara pencoblosan kepada mereka, tetapi memberikan maksud dan tujuan pilkada untuk memilih pemimpin yang mampu memajukan daerah serta mensejahterakan warganya.

Hasil temuan kami masih ada pemilih pemula yang tidak mengetahui tentang Lembaga penyelenggara pemilu yaitu Komisi Pemilihan Umum (KPU) yang bertugas menyiapkan tahapan dan pelaksanaan pemilihan umum. Dan Badan Pengawas Pemilu (Bawaslu) yang bertuga mengawasi tahapan dan pelaksanaan pemilu. terdapat 7 orang atau $17,5 \%$ pemilih pemula yang tidak mengetahui tentang Lembaga tersebut. Sisanya 33 orang atau $82,5 \%$ pemilih mengetahui tentang dua Lembaga tersebut. Ini menunjukkan bahwa Lembaga tersebut belum begitu berhasil dalam memberikan pendidikan pemilih. 


\section{Apakah anda mengetahui tentang lembaga penyelenggara pemilu dan lembaga pengawas pelaksanaan pemilu (KPU dan Bawaslu) \\ 40 responses}
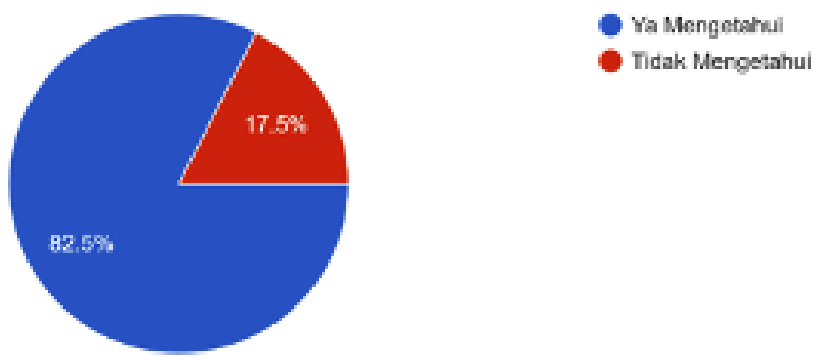

Bahkan masih terdapat pemilih yang tidak mengetahui soal pelaksanaan pilkada serentak pada bulan desember 2020 nanti, ada 9 orang atau 22,5\% pemilih pemula yang belum mengetahui bahwa Provinsi Lampung akan melaksanakan pilkada serentak di 8 kabupaten/Kota. Sementara sisanya 31 orang atau 77,5\% mengetahui bahwa akan ada pelaksanaan pilkada serentak di 8 kabupaten/kota.

\section{Apakah anda mengetahui bahwa 8 Kabupaten/Kota di Provinsi Lampung akan melaksanalan Pemilihan Kepala Daerah (Pilkada) secara serentak pada tanggal 9 Desember 2020 ? 40 responses}

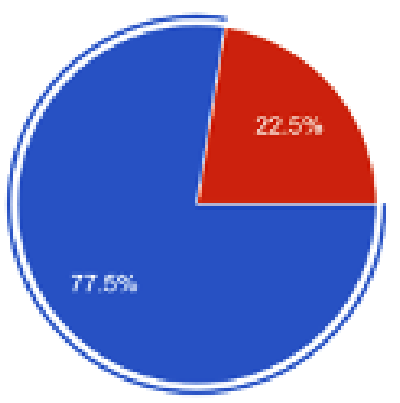

Ya mengetainu

Tidak Menostahui

Kemudian temuan pada pengabdian kami soal politik uang, pada pertanyaan kuesioner soal ketertarikan untuk menerima politik uang, cukup banyak pemilih pemula yang tertarik untuk menerima politik uang ada 17 orang atau $42,5 \%$. Sementara yang tidak tertarik menerima politik uang berjumlah 14 orang atau $35 \%$. Dan yang benar-benar sangat tidak menerima politik uang berjumlah 8 orang atau 20\%. Ini menunjukan bahwa masih ada sebagian pemilih pemula yang mau menerima politik uang pada pilkada nanti, maka perlu pemberian pemahaman bahwa politik uang itu merusak demokrasi karena pemimpin yang terpilih nanti bisa menjabat karena politik uang yang calon tersebut berikan. Dan ini bisa merugikan bagi masyarakat karena pemimpin yang terpilih nanti akan berusaha mengembalikan modal yang telah dikeluarkan dengan kebijakan yang merugikan masyarakat. Berikut ini sebaran persentasenya 


\section{Apakah anda tertarik untuk menerima politik uang Ketika pilkad 2020 nanti 40 reaponses}

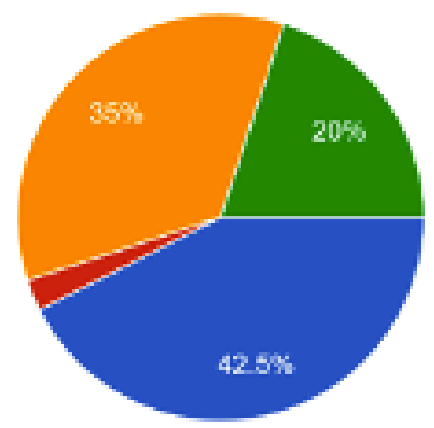

Tertark

Sangat Tertarik

Tidak Terterik

Sangan Tidak Tertarik

Soal pengetahuan mengenai pemahaman penggunaan hak pilih (mencoblos Ketika pilkada) atau kewajiban, masih banyak peserta pengabdian yang menganggap bahwa itu sebagai kewajiban warga negara, terdapat 13 orang atau 32,5\% menganggap sebagai kewajiban. Sementara sisanya sudah mengetahui bahwa menggunak hak pilih (mencoblos ketika pilkada) adalah hak sebagai warga negara, yaitu sebanyak 27 orang atau 67,5\% sudah mengetahui hal tersebut sebagai hak warga negara.

\section{Menurut anda menggunakan hak pilih pada Pemilu (Pileg. Pilpres dan Pilkada) merupakan 40 reaponaes}

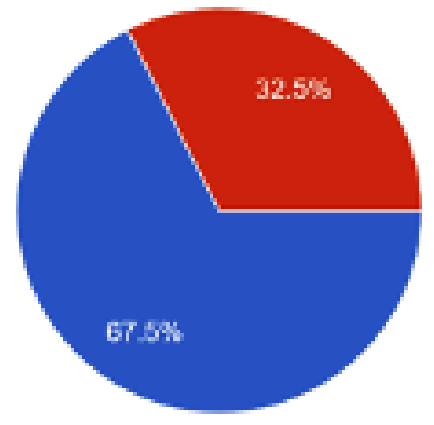

Hok Warga Negars

Kewaliban Warga Nepora

Kemudian kami memberikan kami memberikan materi pengabdian mengenai demokrasi, pilkada, partisipasi politik dan politik uang. Kami memberikan pemahaman kepada para pemilih bahwa tujuan demokrasi adalah menciptakan pemerintahan yang mampu memberi kesejahteraan pada rakyatnya, dan terdapat cara untuk menyeleksi para kandidat kepala daerah melalui pemilihan maka pemilih harus kritis melihat rekam jejak dan latar belakang calon kepala daerah agar terpilih kepala daerah yang benar-benar sesuai dengan aspirasi masyarakat.

\section{KESIMPULAN}

Tingkat pengetahuan pemilih pemula ternyata berbeda-beda, peserta dari daerah Kota Bandar Lampung lebih melek politik dibandingkan dengan peserta dari Kabupaten Lampung Selatan. Karena hasil pre test peserta pengabdian asal Kota Bandar Lampung pengetahuan tentang pilkada lebih baik daripada peserta asal Kabupaten Lampung Selatan. Hal ini terjadi mungkin karena tingkat ekonomi serta keterbatasan akses untuk mendapatkan informasi, karena daerah tempat pengabdian kami di Kecamatan Natar Lampung Selatan ini 
letaknya berbatasan dengan Bandar Lampung tapi kondisi tempat pengabdian kami agak pelosok, karena keterbatasan tersebut kegiatan di Lampung Selatan kami laksanakan dengan tatap muka secara langsung, dipadu dengan tatap muka secara daring dengan peserta dari Bandar Lampung tapi agak terkendala dengan sinyal internet yang tidak stabil tapi terbantu dari tim pengabdian kami yang memberikan materi daring dari Bandar Lampung.

Pengabdian pendidikan pemilih di Lampung Selatan perlu secara berkala diberikan agar tingkat melek politik pemilih pemula di sana bisa lebih baik lagi dibandingkan dengan Bandar Lampung. Pengabdian bisa dilakukan bekerjasama dengan guru mata pelajaran Pendidikan Kewarganegaraan, dan juga Lembaga penyelenggara pemilu seperti KPU dan Bawaslu. Karena [L1] tugas pendidikan politik atau pendidikan pemilih ada juga di Lembaga penyelenggara pemilu yaitu KPU dan Bawaslu. Oleh karena itu sesuai tugas akademisi untuk melakukan Tri Dharma Perguruan Tinggi untuk membantu pendidikan pemilih kepada para pemilih pemula. Sehingga diharapkan pemilih pemula dapat menyebarkan pengetahuan yang mereka dapatkan dalam pengabdian ke masyarakat.

\section{DAFTAR PUSTAKA}

Agustino, Leo. 2009. Pilkada dan Dinamika Politik Lokal. Yogyakarta: Pustaka Pelajar

Budiardjo, Miriam (Ed). 1998. Partisipasi dan Partai Politik: Sebuah Bunga Rampai. Jakarta: Yayasan Obor Indonesia. Gaffar, Affan. 1998. Politik Indonesia Transisi Menuju Demokrasi. Yogyakarta: Pustaka Pelajar.

Haris, Syamsudin (Ed). 2006. Membangun Format baru Otonomi Daerah. Jakarta: LIPI Press

, (Ed). 2005. Desentralisasi dan Otonomi Daerah: Desentralisasi, Demokratisasi dan Akuntabilitas Pemerintahan Daerah. Jakarta: LIPI Press-AIPI-PGRI.

M, Ramses Andy dan Bakry, La Editor. 2009. Pemerintahan Daerah di Indonesia. Jakarta: Masyarakat Ilmu Pemerintahan Indonesia.

Putri, Eka Nora. 2017. Dampak Literasi Politik Terhadap Partisipasi Pemilih Dalam Pemilu. Jurnal Agregasi FISIP UNIKOM, 5(1), 51.

Sutisna, Agus. 2017. Peningkatan Literasi Politik Pemilih Pemula Pada Pembelajaran Kontekstual. Prosiding Seminar Nasional Pendidikan FKIP UNTIRTA, 257

Wardhani, Primandha Sukma Nur. 2018. Partisipasi Politik Pemilih Pemula dalam Pemilihan Umum. Jurnal Pendidikan Ilmu - Ilmu Sosial. 10(1).

http://nasional.kompas.com/read/2014/10/02/21435921/batalkan.pilkada.tak.langsung.presiden.sby.terbitkan.2.perppu 